\title{
Editorial 2022
}

Como citar: Coronel, D. A. (2022). Editorial 2022. Revista de Economia e Sociologia Rural, 60(1), e259653. https://doi. org/10.1590/1806-9479.2021.259653

A Revista de Economia e Sociologia Rural, fiel à sua missão de "Publicar artigos originais e promover o intercâmbio entre profissionais das ciências sociais no Brasil, encorajar o desenvolvimento científico e tecnológico, e estimular internacionalmente a discussão econômica e social", bem como estar alicerçada com as boas práticas editoriais (Silveira \& Silva, 2020; Pesquisa-Fapesp, 2022) vem passando por significativas alterações para aperfeiçoar o seu fluxo editorial, aumentar a sua inserção internacional e buscar a indexação em outras base de dados, tais como Web of Science e Academic One File, da Cengage Learning, além de utilizar as redes sociais e as tecnologias de informação com o objetivo de divulgar os trabalhos e as pesquisas publicadas.

Neste sentido, todas as edições da Revista estão regularizadas, e, cada vez mais, o retorno da primeira rodada de avaliação vem diminuindo. Seguindo essa temática e visando a uma gestão eficiente e eficaz, os artigos aceitos e/ou publicados a partir do volume 60, de 2022, terão alterações no seu fluxo editorial, a saber: a) para artigos aprovados em português ou espanhol, será opcional a tradução para a língua inglesa. Assim, a publicação ocorrerá nos dois idiomas, e os autores serão responsáveis pelos custos da tradução; b) será necessária uma declaração informando que o texto passou por revisão gramatical de um profissional ou empresa especializada. Se optar pela publicação nos dois idiomas, será preciso uma declaração de tradução; e c) a taxa de processamento para a publicação do artigo em um idioma será de $\mathrm{R} \$ 500,00$ (quinhentos reais) e em dois idiomas será de $\mathrm{R} \$ 800,00$ (oitocentos reais).

Tais ações visam qualificar ainda mais a redação dos artigos publicados bem como a solidez financeira da Revista, para que, dessa forma, continue mantendo com regularidade e acuidade os artigos publicados com diagramação e layout de qualidade.

Por fim, reitero, de maneira peremptória, os meus agradecimentos a todos(as) os(as) soberianos(as), ao Conselho Editorial, aos editores associados e aos pareceristas, bem como o nosso compromisso institucional de difundir os resultados de pesquisas originais nas áreas de Economia, Administração, Sociologia Rural e afins e, por consequência, promover e estimular o debate de temas e fenômenos de importância econômica e social, além de colaborar para o desenvolvimento científico e tecnológico do Brasil e das outras comunidades científicas de outros países.

A todos(as) os nossos sinceros desejos de uma boa leitura!!!

Prof. Dr. Daniel Arruda Coronel' 1 (1)

Editor-chefe da Revista de Economia e Sociologia Rural (RESR)

1 Universidade Federal de Santa Maria (UFSM), Santa Maria (RS), Brasil. E-mail: daniel.coronel@uol.com.br

\section{Referências}

Pesquisa-Fapesp. (2022). Boas práticas. Recuperado em 20 de fevereiro de 2022, de https:// revistapesquisa.fapesp.br/category/impressa/boas-praticas.

Silveira, L., \& Silva, F. C. C. (2020). Gestão editorial de periódicos científicos: tendências e boas (1. ed.). Florianópolis: UFSC - BU Publicações, Edições do Bosque. 